\title{
$\mathrm{Al}-\mathrm{Si}$ 도금된 핫스탬핑 보론강의 볼트 프로젝션 용접시 예열 통전이 용융 거동에 미치는 영향 \\ 김재훈 · 전현욱 · 천주용 · 김재원 · 김재득 · 지창욱* \\ 한국생산기술연구원 울산지역본부
}

\section{The Effect of Preheating Current on the Melting Behavior of Bolt Projection Welding of Al-Si Coated Hot-Stamped Boron Steel}

\author{
Jae-Hun Kim, Hyun-Uk Jun, Joo-Yong Cheon, Jae-won Kim, Jae-deuk Kim, and Changwook Ji*
} Ulsan Regional Division, Korea Institute of Industrial Technology, Ulsan 44776, Republic of Korea

\begin{abstract}
This study evaluated the effect of preheating on early stage melting behavior of a $\mathrm{Al}-\mathrm{Si}$ coated hot stamped boron steel bolt during projection welding. A large amount of heat was generated in the early stage of projection welding. Because of the large heat generation, a rapid collapse of the projection occurred and a molten coating layer remained on the interface of the welded part. This caused welding defects such as expulsion and porosity. However, preheating helped remove the molten Al-Si coating layer by pushing it out toward the outer edge of the molten pool. This suggests that preheating can effectively minimize or remove the molten coating layer within the weld. Preheating also prevented the rapid collapse of the projection by partially melting the projection, and thus improving the contact area. These phenomena can prevent the concentration of current density at the weld interface and hence decrease heat generation. Finally, the preheating current improved nugget quality by promoting the stable growth of the melted metal and by preventing expulsion and porosity.
\end{abstract}

(Received July 23 2021; Accepted August 25, 2021)

Keywords: bolt projection welding, preheating current, Al-Si coated hot-stamping steel, initial melting behavior. SORPAS simulation

\section{1. 서 론}

전 세계적으로 자동차 배기가스로 인한 대기오염 저감을 위해 자동차 온실가스 배출허용기준 및 연비규제가 강화됨 에 따라 국내외 자동차산업은 하이브리드/전기/수소 연료전 지 자동차 등과 같은 친환경 동력 자동차 개발에 몰두하고 있다 [1]. 특히 친환경 동력 자동차는 주행거리 확보를 위 해 경량화가 필수이며, 경량화를 위해서는 $\mathrm{Al}, \mathrm{CFRP}$ 등 경 량소재 적용, 초고장력강판을 이용하여 차체 경량화 기술 이 고도화 되고 있다 [2]. 탑승자의 안전과 직결되어 높은 강성을 요구하는 $\mathrm{A}$ 필러, $\mathrm{B}$ 필러 등의 부품은 안정성과 경

- 김재훈·천주용: 연구원, 전현욱·김재득: 박사과정, 김재원: 박사후연구원, 지창욱: 수석연구원

*Corresponding Author: Changwook Ji

[Tel: +82-10-6606-4068, E-mail: cwji@kitech.re.kr]

Copyright (c) The Korean Institute of Metals and Materials
량화를 모두 확보하기 위해 초고장력강이 주로 사용되어지 고 있다. 초고장력강의 경우 성형시 높은 강성으로 인해 스프링백 현상이 발생해 냉간성형이 난이 하여 단점을 극 복하기 위해 고온에서 성형과 냉각을 동시에 진행하는 핫 스탬핑 공법을 통해 제품을 제작한다. 핫스탬핑 공법은 $400 \sim 500 \mathrm{MPa}$ 급 강판을 $900 \sim 950{ }^{\circ} \mathrm{C}$ 의 높은 온도에서 금 형을 활용하여 성형과 냉각을 동시에 진행하는 공법으로 [3] 고온산화 및 탈탄을 방지 하기 위해 강판 표면에 내식 성이 우수한 $\mathrm{Al}$ 을 강판표면에 도금하며 도금시 합금상 생 성억제를 위해 $\mathrm{Si}$ 을 일부 첨가한다. $900 \sim 950{ }^{\circ} \mathrm{C}$ 의 높은 온도에서 성형되는 핫스탬핑 공정상 $\mathrm{Fe}-\mathrm{Al}-\mathrm{Si}$ 중간화합물 층이 생성되고 복잡한 합금화층 및 산화층으로 구성되어 있다 [4]. 합금화층은 불연속 구조의 금속간 화합물로 이루 어져 있고, 최외각에 생성된 산화층은 높은 저항을 갖고 있다. 핫스탬핑공법이 적용된 제품의 경우 자동차 산업에 서 주로 저항 점용접, 프로젝션 용접 등 저항 용접 공법을 
이용해 제품을 조립하며 핫스탬핑강의 산화층 및 복잡한 합금화층은 저항 용접시 다양한 문제점을 발생시킨다 [57] 용접 후에 생성되는 $\mathrm{Fe}-\mathrm{Al}_{2}$ 상은 높은 취성을 갖고 용 접부 계면에 존재할 경우 강도를 저하시키고 용접시 외각 으로 밀려나 코로나본드에 잔존하는 $\mathrm{Al}-\mathrm{Si}$ 도금층은 파단 시 노치로 작용한다 [8].

핫스탬핑강 프로젝션 용접의 경우 복잡한 합금화층과 소 재의 높은 강성에 의해 스패터, 용착강도 저하, 가용전류구 간이 확보되지 않아 작업 현장에서는 Shot blat 공정을 통 해 물리적으로 용접부의 도금층을 제거하거나, $\mathrm{CO}_{2}$ 용접을 이용해 보수용접을 하는 등 추가 공정을 통해 접합부 물성 을 만족하고 있는 실정이다. 이러한 문제점을 해결하기 위 한 선행 연구 사례로는 Luo의 짧은 시간 동안 전류를 방 출하는 Capacitor Discharge 용접법을 이용한 연구 [9]와 Chun의 너트 돌기 형상을 개선하거나 [10], Lim의 너트의 재질에 따른 용접성 분석 [11] 등의 돌기의 재질 및 형상 에 따른 용접성 개선 연구가 진행 됐다. 반면 핫스탬핑강 저항 점 용접의 용접성 개선 연구는 추가 공정 및 비용이 발생하지 않는 다단통전을 이용한 연구가 진행되었다. $\mathrm{Ji}$ 등은 저항 점 용접시 $\mathrm{Al}$ 도금 과 $\mathrm{Zn}$ 도금 핫스탬핑강판 합금층의 영향을 비교 분석하고 전류의 파형제어를 통해 최적용접조건을 도출하였고 [12], chen은 멀티 펄스 전류 파형을 이용하면 노치로 작용하는 $\mathrm{Al}-\mathrm{Si}$ 합금화층을 최소 화 할 수 있다고 보고하였다 [13]. 공정상 이점이 있는 다 단통전을 프로젝션 용접공법에도 적용하고자 하나 돌기의 형상에 의해 전류밀도가 결정되는 프로젝션용접의 경우 전 극형상에 의해 전류밀도가 결정되는 저항 점 용접의 연구 결과를 적용하기에는 무리가 있다.

이에 앞선 연구에서는 볼트 프로젝션 용접시 $\mathrm{Al}-\mathrm{Si}$ 합금 화층이 용접성에 미치는 영향을 분석하기 위해 Al-Si 도금 층을 물리적인 방법으로 제거 후 도금층 유무에 따른 용융 거동을 분석하였으며 [14], 본 연구에서는 $\mathrm{Al}-\mathrm{Si}$ 도금된 핫 스탬핑 보론강의 볼트 프로젝션 용접시 다단 통전의 한 방
법인 예열 통전을 적용하여 예열 통전의 영향에 의해 용접 초기 도금층 거동과 돌기 붕괴현상을 분석하고, 용접초기 도금층 및 용접부 용융 거동에 따른 용접부 물성 및 너겟 경 성장을 비교해 보았다.

\section{2. 실험 방법}

본 연구에서는 $900{ }^{\circ} \mathrm{C}$ 에서 약 5 분간 유지 후 냉각다이에 서 급냉한 $1.0 \mathrm{~mm}$ 의 두께를 갖는 $\mathrm{Al}-\mathrm{Si}$ 도금된 핫스탬핑 보론강판과 $\mathrm{KS} \mathrm{B} 1057$ 규격의 3점 돌기를 갖는 탄소강 M6 볼트를 사용 하여 프로젝션 용접하였다. 실험에 사용 된 $\mathrm{Al}-\mathrm{Si}$ 도금된 핫스탬핑 보론강과 탄소강 $\mathrm{M} 6$ 볼트의 성분은 Table 1에 나타내었으며 미세조직은 그림 1과 같다. $\mathrm{Al}-\mathrm{Si}$ 도금된 핫스탬핑 보론강은 미세한 침상 마르텐사이 트 조직이며, 탄소강 볼트는 페라이트와 일부 펄라이트의 조직으로 보여 진다. 용접 장비는 그림 2와 같이 전격 용 량 $100 \mathrm{kvA}$, 제어주파수 $1000 \mathrm{~Hz}$ 의 Inveter $\mathrm{DC}$ 정치식 공압 저항 용접기를 사용 하였고 전극은 $25^{\circ} \mathrm{C}, 6.0 \mathrm{~L} / \mathrm{mm}$ 로 냉각하였으며, 전극은 직경 $20 \mathrm{~mm}$ 인 평팁 전극을 사 용하였다. 실시간으로 전류, 전압을 모니터링하여 동저항 곡선을 계산하였다. 용접조건은 실제 작업 현장 조건을 반 영하였고, 예열통전 조건의 경우 도금층이 용융될 수 있고, 돌기가 완전히 무너지지 않는 조건을 선정하였다. 일반적인 용접조건과 예열 통전을 포함한 용접조건을 비교 분석 하
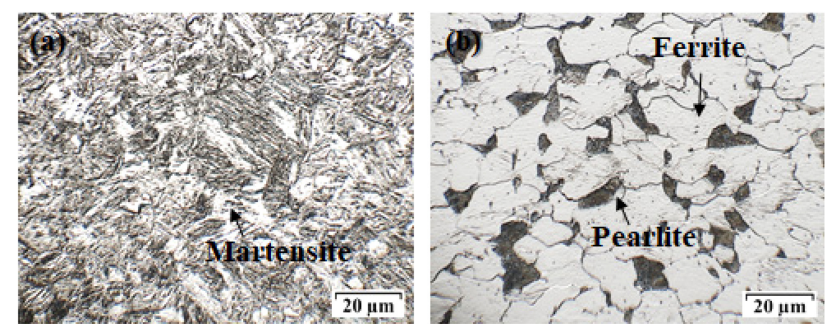

Fig. 1. Microstructure for various base metals: (a) hot stamping boron steel, (b) carbon steel bolt.

Table 1. Chemical composition of Al-Si coated hot stamping boron steel and carbon steel bolt.

\begin{tabular}{|c|c|c|c|c|c|c|c|c|c|}
\hline \multicolumn{10}{|c|}{ Chemical composition of hot stamping born steel (wt $\%)$} \\
\hline $\mathrm{C}$ & $\mathrm{Si}$ & $\mathrm{Mn}$ & $\mathrm{P}$ & $\mathrm{S}$ & $\mathrm{Al}$ & $\mathrm{Ti}$ & B & $\mathrm{Cr}$ & $\mathrm{Fe}$ \\
\hline 0.22 & 0.26 & 1.21 & 0.019 & 0.003 & 0.036 & 0.039 & 0.003 & 0.19 & Bal \\
\hline \multicolumn{10}{|c|}{ Chemical composition of hotstapming born steel coating $(\mathrm{wt} \%)$} \\
\hline \multicolumn{10}{|c|}{$\mathrm{Al}$} \\
\hline \multicolumn{3}{|c|}{ Bal } & \multicolumn{5}{|c|}{10} & & \\
\hline \multicolumn{10}{|c|}{ Chemical composition of carbon steel bolt(wt $\%)$} \\
\hline \multicolumn{2}{|c|}{$\mathrm{C}$} & \multicolumn{2}{|c|}{$\mathrm{Mn}$} & \multicolumn{2}{|c|}{$\mathrm{P}$} & \multicolumn{2}{|c|}{$\mathrm{S}$} & \multicolumn{2}{|c|}{$\mathrm{Fe}$} \\
\hline \multicolumn{2}{|c|}{0.15} & \multicolumn{2}{|c|}{0.45} & \multicolumn{2}{|c|}{0.010} & \multicolumn{2}{|c|}{0.031} & \multicolumn{2}{|c|}{ Bal } \\
\hline
\end{tabular}




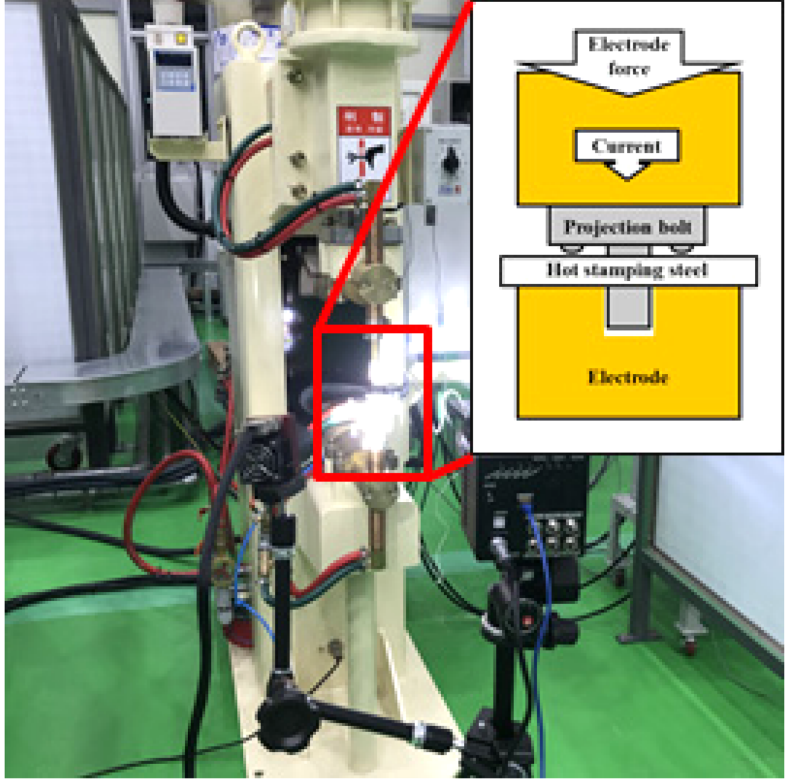

Fig. 2. Experimental set up of bolt projection welding.

기 위해 예열 통전의 유무에 따른 예열 통전을 포함하지 않 는 용접 조건(Without pre heat welding condition(이하 W/O $\mathrm{PHC})$ ), 예열 통전을 포함하는 용접조건(With pre heat welding condition(이하 $\mathrm{W} \mathrm{PHC})$ ) 로 2종류의 용접조건을 설정하였으며 구체적인 용접조건은 그림 3에 나타내었다. 예열 통전이 용접성에 미치는 영향을 분석하기 위해 압축 시험을 통하여 용착강도 측정을 하였으며 최소 용착강도 $420 \mathrm{kgf}$ 이상을 만족하는 전류를 하한 전류로, 중간날림이 발생하는 전류를 상한 전류로 설정하여 가용전류 구간을

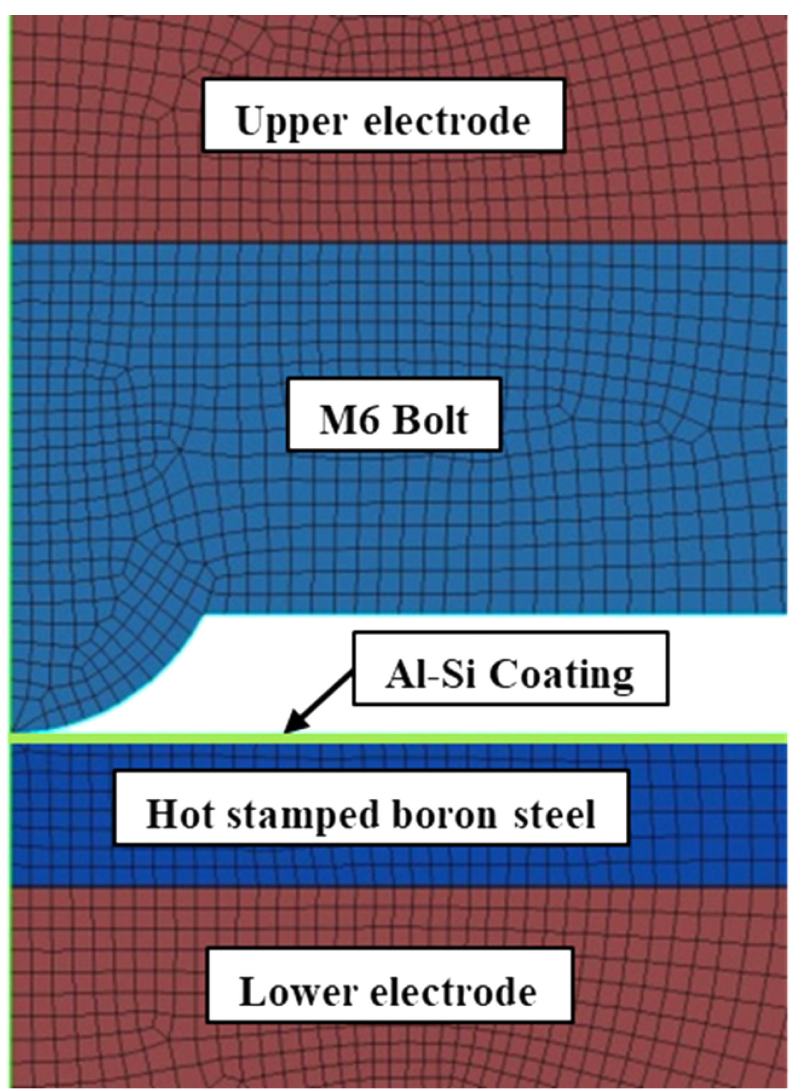

Fig. 4. FEM Model for bolt projection welding by $\operatorname{sorpas} \AA$ simulation.

설정하였다. 용접초기 용융현상과 도금층의 거동에 미치는 영향을 분석하기 위해 광학현미경을 이용해 도금층을 관찰 하였고, 도금층 제거 현상을 관찰하기 위해 EPMA (Electron

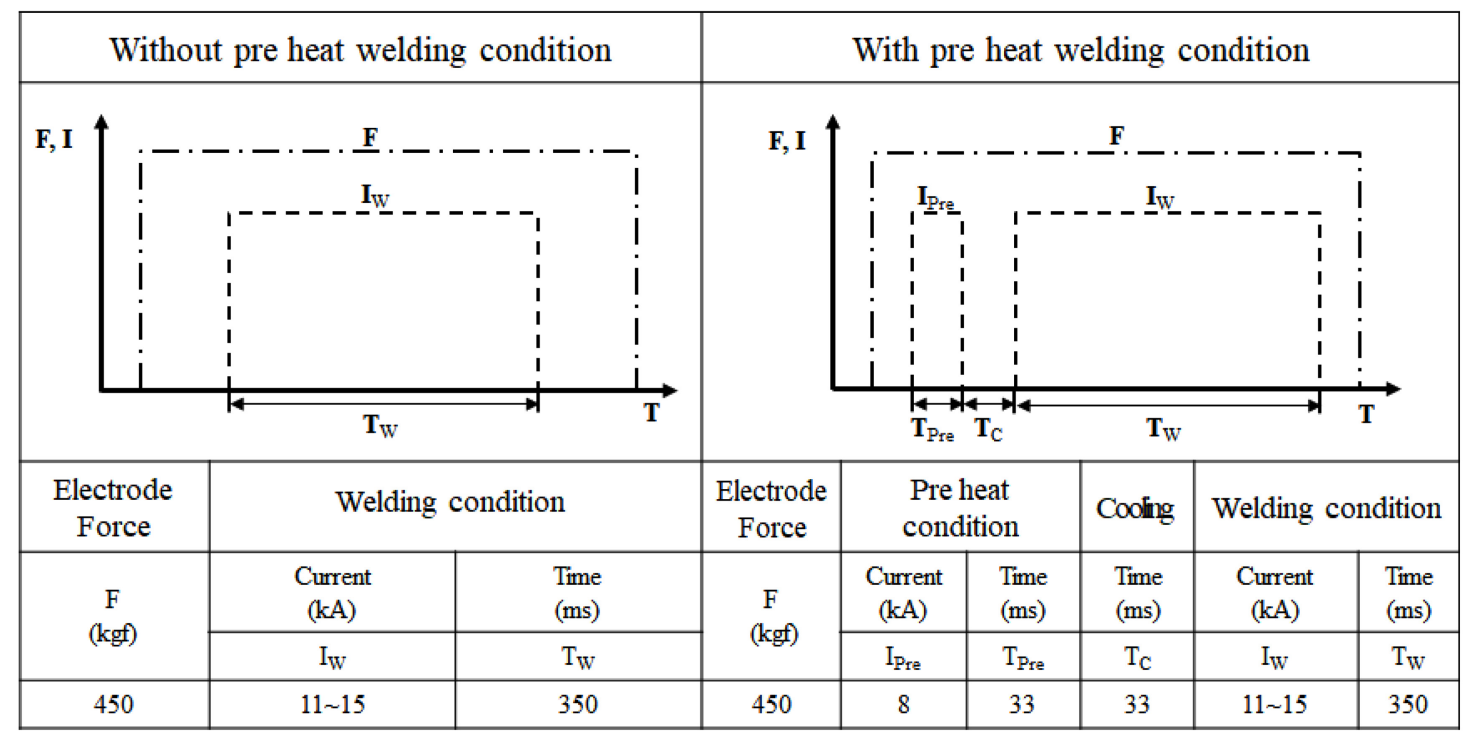

Fig. 3. Schedule of bolt projection welding conditions. 
Probe Micro Analysis)의 성분 맵핑(Mapping) 기법을 이용하 여 분석하였다. 용접시간에 따른 용융 현상 비교분석 하였 으며, 미세조직 구조와 경도를 비교 분석하여 용융부와 열 영향부를 고찰하였다. 돌기의 붕괴과정, 전류밀도, 온도 등 은 실제 용접시 관찰이 어렵기 때문에 $\mathrm{SORPAS} \AA$ 프로그 램을 이용하여 용접현상을 $2 \mathrm{D}$ 로 해석 하였다. $2 \mathrm{D}$ 해석 특성상 3점 돌기의 구현이 불가능하여 그림 4와 같이 1점 돌기로 모델링 하여 해석 수행 하였으며 시편의 치수와 소 재는 실제 조건과 동일하게 구현하였고, 해석에 사용된 용 접조건은 1점 돌기에 맞게 실제 용접 조건과 유사한 조건 으로 설정하였다.

\section{3. 실험 결과 및 고찰}

\section{1 예열통전 유무에 따른 용접성 비교}

그림 5는 용접성과 예열 통전의 영향을 비교하기 위해 예열 통전의 유무에 따른 가용전류구간을 도출한 결과로 완성차업체에서 요구하는 M6 볼트 프로젝션 용접에서 확 보되어야할 최소 용착강도인 $420 \mathrm{kgf}$ 이상을 가용전류 구 간으로 판단하고 중간날림이 발생하기 직전까지 가용전류 구간으로 설정하였다. W/O PHC(without preheat welding condition) 조건은 중간날림 발생 이하 조건인 $11,12 \mathrm{kA}$ 의 용접조건에서 용착강도 약 $200 \mathrm{kgf}$ 를 확보 하였으며, $13 \mathrm{kA}$ 이상의 용접조건에서 용착강도가 저하되어 가용전류 구간을 확보하지 못하였으며 이는 중간날림의 발생으로 인 해 용착강도가 저하된 것으로 판단된다. 반면 $\mathrm{W} \mathrm{PHC}$ (with preheat welding condition) 조건의 경우 $13 \mathrm{kA}$ 용

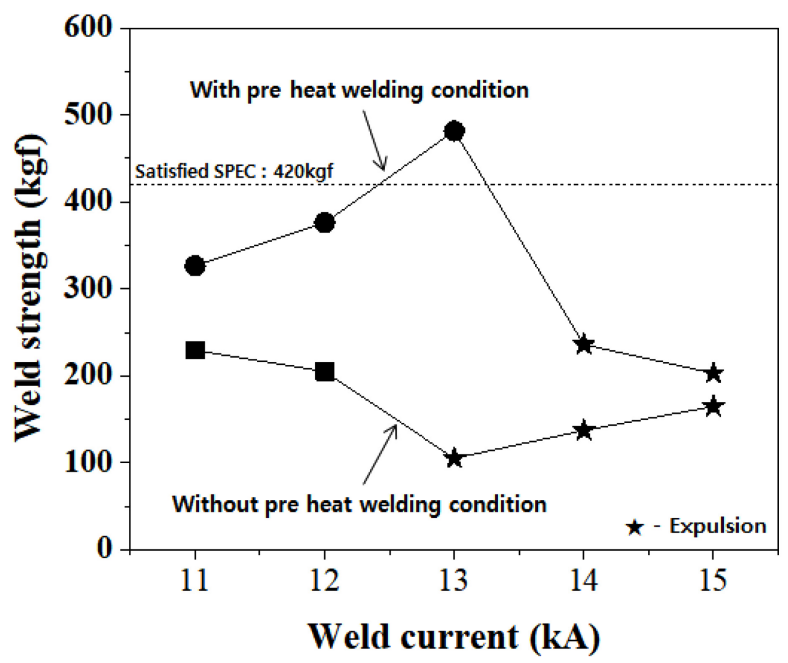

Fig. 5. Comparison of weldable current range for various preheating conditions.

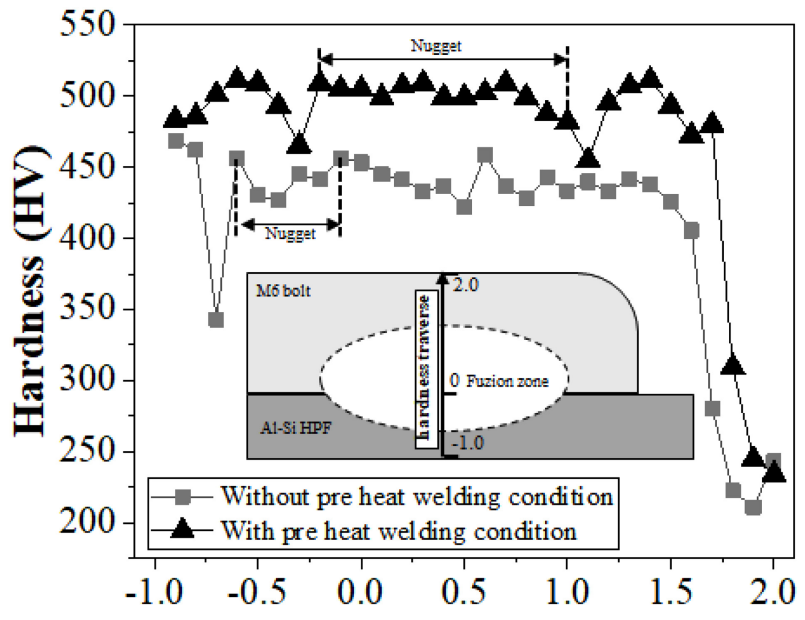

\section{Distance from weld center ( $\mathrm{mm})$}

Fig. 6. Micro-Vickers hardness profile after bolt projection welding.

접조건에서 최대 용착 강도 약 $480 \mathrm{kgf}$ 를 확보할 수 있으 며 $14 \mathrm{kA}$ 이상의 용접조건에서 중간날림이 발생 하여 용 착강도가 저하 되었다. 용착강도가 확보된 전류조건 $13 \mathrm{kA}$ 의 용접부 계면을 $\mathrm{Al}-\mathrm{Si}$ 도금된 핫스탬핑강부터 볼트까지 의 경도를 측정한 결과를 그림 6 와 같이 그래프로 나타내 었다. 열영향을 받지 않은 모재 가장자리 부분을 제외하고 $\mathrm{Al}-\mathrm{Si}$ 도금된 핫스탬핑강 열영향부, 용융부, 볼트 열영향부 모두 W/O PHC 조건이 약 $50 \mathrm{Hv}$ 가량 낮게 나타났다. 기존 $\mathrm{Al}-\mathrm{Si}$ 도금된 핫스탬핑강의 모재는 $450 \sim 500 \mathrm{Hv}$, 탄 소강 볼트는 $200 \sim 250 \mathrm{Hv}$ 정도로 측정되었으며 W PHC 조건의 경우 정상적인 용접부에서 나타나는 수준의 경도가 나타났고, 용융부 주변에 조대 결정립에 의해 경도가 감소 하였다. 반면 $\mathrm{W} / \mathrm{O} \mathrm{PHC}$ 조건은 용융부와 열영향부의 경 도가 약 420 450 Hv로 $\mathrm{Al}-\mathrm{Si}$ 도금된 핫스탬핑강 모재의 수준보다 낮게 나타났다. 이는 예열 통전의 유무에 따른 용융거동의 차이로 판단되며 예열 통전을 통한 도금층 용 융거동 및 용접부 물성 및 미세조직에 대해 3-2절부터 고 찰해 보았다.

\section{2 용융부 성장거동}

앞선 결과를 정리 해보면 $\mathrm{W} \mathrm{PHC}$ 조건은 $\mathrm{W} / \mathrm{O} \mathrm{PHC}$ 조건 보다 더 높은 용접부 강도를 얻을 수 있었고 또한 가용전류구간이 확보되었다. 이는 예열 통전에 의해 용융 부의 성장거동이 다른 것으로 판단되며 이에 용접 초기부 터 용접종료까지 시간에 따른 용접부 계면의 용융부 성장 거동을 관찰한 결과를 그림 7 에 나타내었다. 


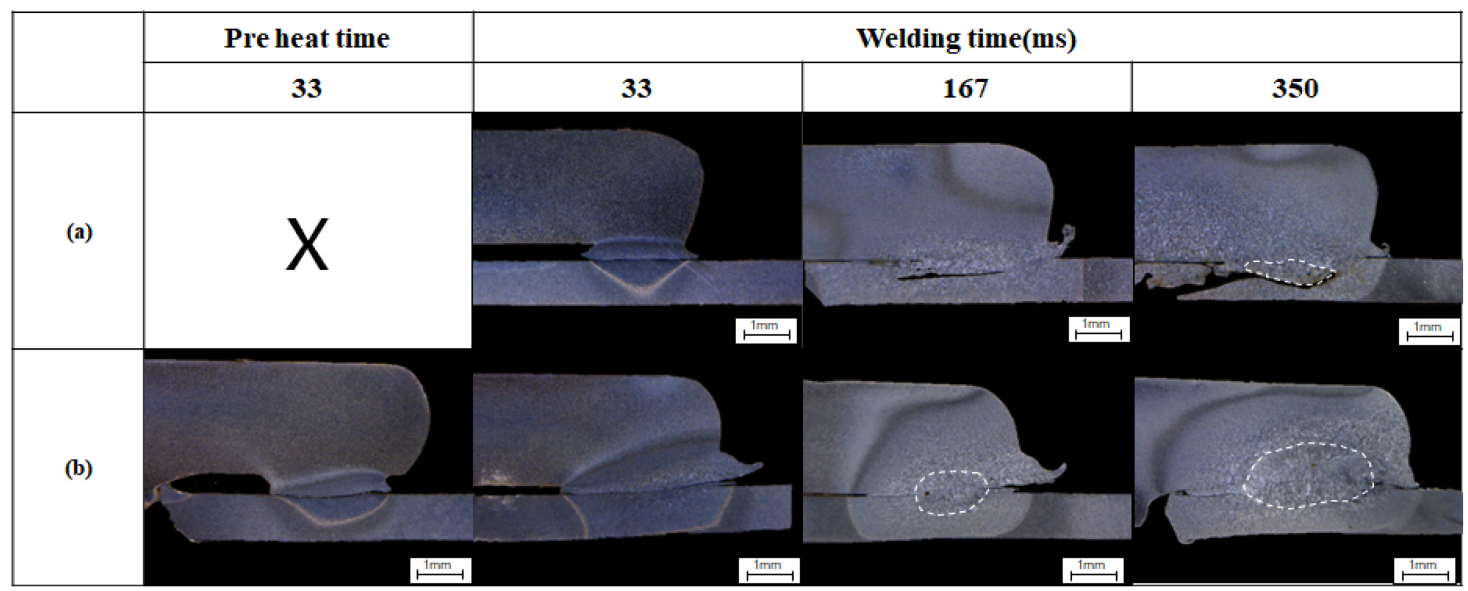

Fig. 7. Comparison of nugget growth using weld current $13 \mathrm{kA}$ for various preheating conditions: (a) with out preheating, (b) With preheating.

입열 패턴을 비교한 결과 $\mathrm{W} / \mathrm{O} \mathrm{PHC}$ 조건은 용접시간이 $167 \mathrm{~ms}$ 때 용융부가 생성 되지 않았고, 중간날림으로 인해 용융물이 외각으로 빠져나가 용접부 계면 아래에서 얇고 긴 형태의 기공이 관찰되었다. 이후 최종 $350 \mathrm{~ms}$ 에서 용융 부가 관찰되었으나 크기가 작고 용융부 바로 아래 열린형 태의 기공이 관찰되었다. 본 기공의 생성은 과도한 입열에 의한 날림에 기인한 것 이라고 판단되고, 본 기공과 같은 결함이 용접부의 파단모드에 영향을 미칠 것으로 판단된다 [15-18]. 반면 W PHC 조건은 용접시간 $33 \mathrm{~ms}$ 때 $\mathrm{W} / \mathrm{O}$ $\mathrm{PHC}$ 조건에 비해 넓은 접촉면적을 확보하였으며 이후 용 접시간 $167 \mathrm{~ms}$ 에서 너깃이 안정적으로 성장하였고, 최종 용접시간 $350 \mathrm{~ms}$ 에서 정상적인 너깃이 형성되었음을 관찰
하였다. 예열통전은 가압에 의해 돌기의 일부가 붕괴된 상 태에서 용접초기시간동안 용접전류가 예열형태로 인가되는 것을 의미한다. 이로 인해 $\mathrm{Al}-\mathrm{Si}$ 도금층이 외각으로 밀려 나면서 용접부의 통전 면적을 안정적으로 확보할 수 있고, 용접시간동안 선형적 너겟 성장을 유도함에 따라 예열통전 으로 인한 도금층의 영향을 최소화할 수 있다.

\section{3 용접 시뮬레이션을 이용한 용접초기 용융거동 예측}

볼트 프로젝션 용접의 경우 돌기의 형상 및 크기에 따라 전류밀도가 변화하여 용접초기 돌기의 형상과 돌기 붕괴속 도는 용접결과에 중요한 영향을 미친다. 용접초기의 온도, 전류밀도, 압흔 등 용접현상에 대한 정량적인 비교 분석을

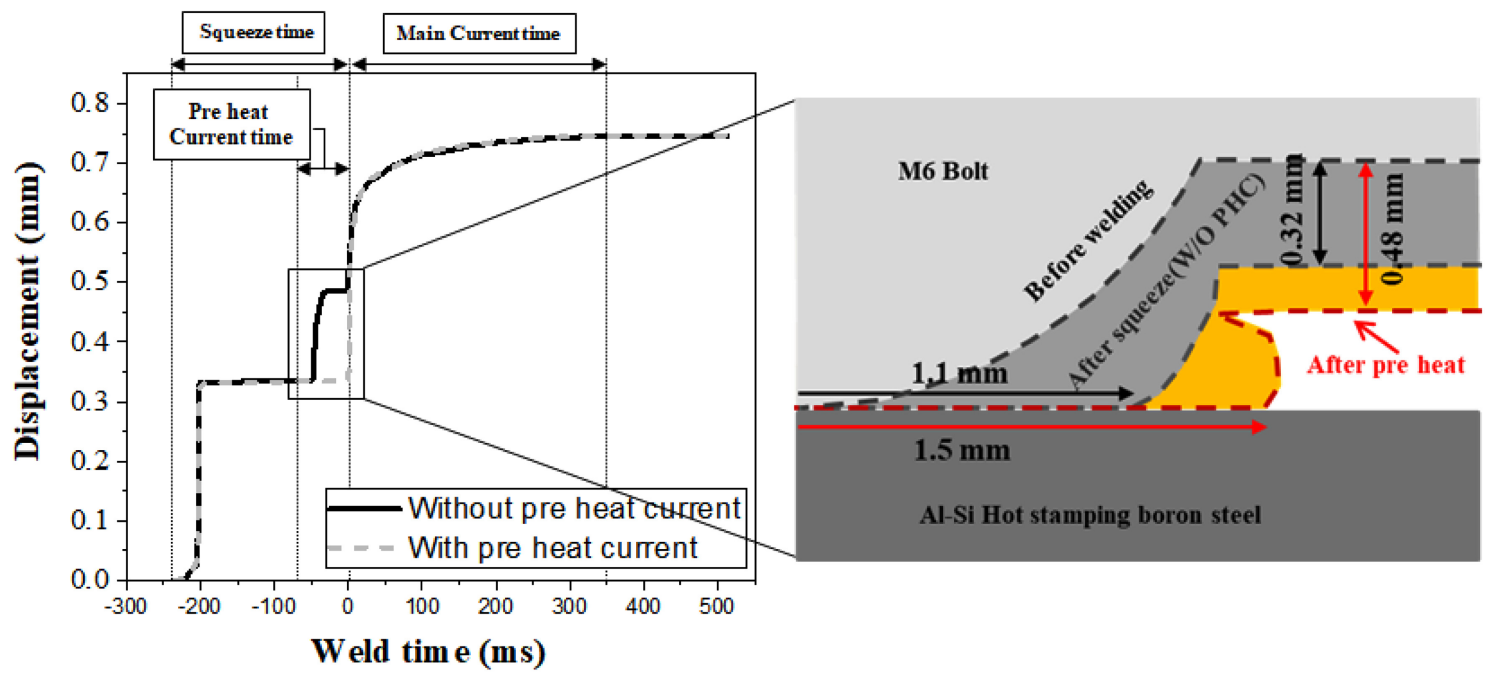

Fig. 8. Comparison of projection collapse displacement using SORPAS ${ }^{\circledR}$ simulation with or without preheating. 


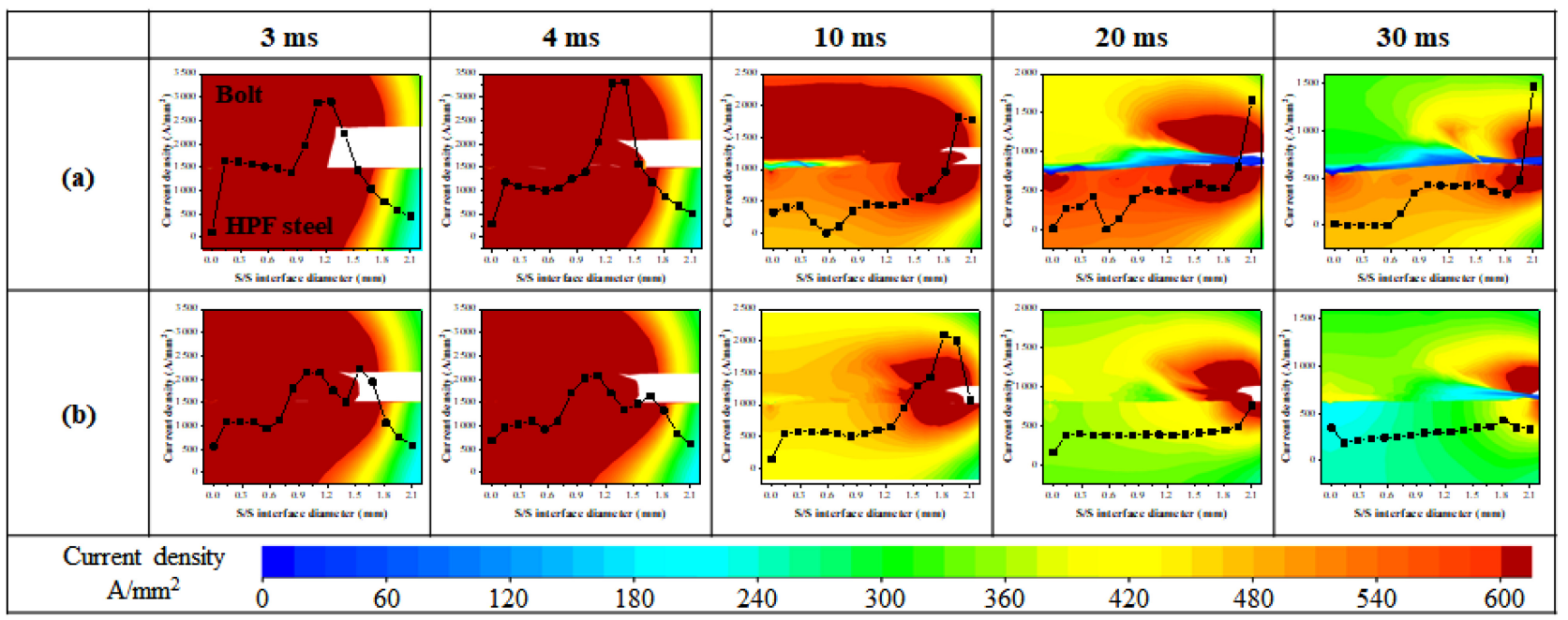

Fig. 9. Distributions of welding current density in $\mathrm{S} / \mathrm{S}$ interface by SORPAS ${ }^{\circledR}$ simulation for various preheating conditions: (a) without preheating, (b) With preheating.

위해 SORPAS $®$ 해석 시뮬레이션을 이용해 용접초기 예열 통전이 미치는 영향을 분석하였다 [19-21].

그림 8 에 나타낸 그래프와 같이 용접부 계면을 안정시키 는 초기가압 시간에 돌기가 붕괴되는 거리는 $0.32 \mathrm{~mm}$ 이 고, 예열 이후에 붕괴되는 거리는 $0.48 \mathrm{~mm}$ 이다. $\mathrm{W}$ $\mathrm{PHC}$ 조건의 경우 예열통전의 영향에 의해 돌기가 일부 붕 괴되고 용접전류가 인가되지만 돌기가 최대로 붕괴 되는 시간은 $\mathrm{W} / \mathrm{O} \mathrm{PHC}$ 조건과 동일하였다. 이는 W/O PHC조 건에서의 돌기붕괴 속도가 빠른 것을 의미하고, 돌기의 빠 른 붕괴는 용접부 계면사이 접촉의 안정화 시간이 부족하 여 중간날림, 기공 등 용접 불량이 발생할 확률이 높다. 용접전류가 인가되는 돌기와 판재 사이의 접촉면적은 $\mathrm{W} /$ $\mathrm{O} \mathrm{PHC}$ 조건 $1.1 \mathrm{~mm}, \mathrm{~W} \mathrm{PHC}$ 조건 $1.55 \mathrm{~mm}$ 로 W $\mathrm{PHC}$ 조건이 더 넓게 관찰되었다. 용접 초기 넓은 접촉면적을 가지게 되면 용융부 발열이 안정되어 용접부의 안정적인 성장에 용이 하고 중간날림 발생, 기공 등 용접불량이 발 생할 인자를 줄일 수 있다.

볼트 프로젝션의 경우 돌기 형상이 전류밀도에 영향을 미치기 때문에 그림 9 와 같이 용접초기 붕괴거동이 상이 한 용접시간 5 20 ms 일 때 예열 통전의 유무에 따른 $\mathrm{S} /$ $\mathrm{S}$ 계면의 전류밀도 및 분포를 분석하였다. 용접전류 통전 이후 용접시간 $3 \mathrm{~ms}$ 때 $\mathrm{W} / \mathrm{O} \mathrm{PHC}$ 조건에서는 돌기가 급 격하게 붕괴되면서 용접부 중심 외각에서 전류밀도의 집중 이 높았으나 $\mathrm{W} \mathrm{PHC}$ 조건은 예열에 의해 일부 붕괴가 된 상태에서 용접전류가 인가되어 비교적 용접부 중심 외 각에서 전류밀도가 집중되지 않았다. 이후 $\mathrm{W} / \mathrm{O} \mathrm{PHC}$ 조
건은 용접부 중심 계면의 전류밀도가 약 $0 \sim 500 \mathrm{~A} / \mathrm{mm}^{2}$ 편 차가 있었고 $10 \mathrm{~ms}$ 까지 높은 전류밀도의 집중이 관찰되 었다. 이는 용융된 돌기에 의해 전류밀도의 흐름이 방해되 어 돌기부에서 높은 전류밀도가 관찰된 것으로 판단된다. 반면 $\mathrm{W} \mathrm{PHC}$ 조건은 $10 \mathrm{~ms}$ 이후 용접부 중심이 안정화 되었으며 용접부 외각에 전류밀도가 집중되었고 $20 \mathrm{~ms}$ 이 후 전류밀도는 약 $120 \sim 350 \mathrm{~A} / \mathrm{mm}^{2}$ 으로 나타났다. 용접 초 기 예열통전에 의해 돌기가 일부 무너진 상태에서 전류가 통전됨에 따라 넓은 접촉면적을 갖고 돌기의 붕괴속도가 느렸기 때문에 전류밀도가 더 빨리 안정화 되었다 [22].

저항 용접은 전류밀도에 의해 국부적으로 저항열을 발생 시켜 가압과 함께 용융 접합 시키는 방법으로 전류밀도의 차이는 용융부의 발열거동 및 온도분포와 밀접한 관계가 있어 예열 통전의 유무에 따른 용접초기 용융현상을 그림 10 과 같이 나타내었다. $\mathrm{W} / \mathrm{O} \mathrm{PHC}$ 조건의 경우 용접 초기 $5 \mathrm{~ms}$ 이내에 용접부 중심 외각에서 급격한 온도의 상승이 관찰되었으며 $3 \mathrm{~ms}$ 에 용접부 외각에서 용융물이 관찰되었 다. 돌기의 붕괴 과정도 동시에 진행됨에 따라 용접부 외 각으로 용융물이 배출되는 중간 날림 현상이 관찰되었다. 반면 $\mathrm{W} \mathrm{PHC}$ 조건은 용접초기 급격한 온도의 상승이 관 찰되지 않았고 약 $10 \mathrm{~ms}$ 이후 용접부 외각에서 용융물이 형성되고 이후 용접부 중심으로 성장되어 안정적인 용융부 의 성장을 관찰 할 수 있었다. 용접부 온도분포의 차이는 돌기의 붕괴와 $\mathrm{Al}-\mathrm{Si}$ 도금층의 영향에 의한 접촉 저항 및 면적에 의한 차이에 기인한 것으로 판단된다.

$\mathrm{Al}-\mathrm{Si}$ 도금된 핫스탬핑강의 경우 $\mathrm{Al}-\mathrm{Si}$ 도금층에 기인한 


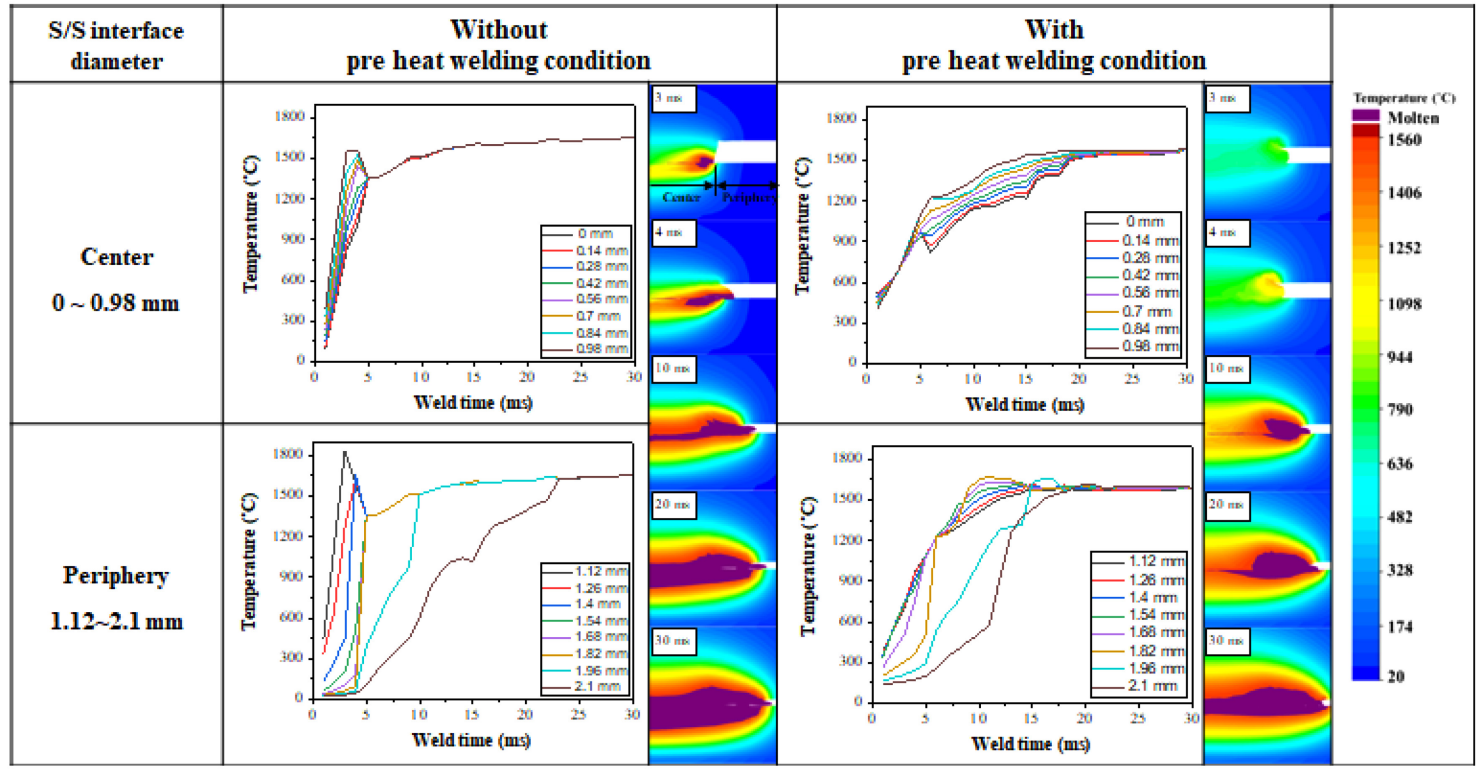

Fig. 10. Temperature distributions and melting behavior in $S / S$ interface by SORPAS ${ }^{\circledR}$ simulation.

높은 접촉 저항을 용접초기 예열통전을 통해 접합계면 및 접촉계면의 $\mathrm{Al}-\mathrm{Si}$ 도금층을 제거하여 접촉 저항을 감소시 키고, 돌기가 붕괴되는 과정에서 용접부의 통전 면적을 안 정적으로 확보하여 너겟의 선형적 성장 유도를 통해 용접 성을 개선하는 것이 주요해결책이다. 예열 통전을 적용하 면 용접초기 돌기를 일부 붕괴시켜 안정적인 접촉 면적을 확보하고 전류밀도의 편중을 방지 할 수 있었으며, 접촉면 적 확보와 동시에 선형적 너겟 성장을 유도하기 때문에 중
간날림 현상을 최소화하고 용접특성을 향상시킬 수 있다.

\section{4 용융초기 도금층 용융거동 및 동저항 거동 분석}

예열 통전이 $\mathrm{Al}-\mathrm{Si}$ 도금층 용융거동에 미치는 영향에 대 한 상세분석을 위해 예열통전 직후의 용접부 단면을 EPMA Mapping 을 이용해 그림 11과 같이 성분분석 하였다. 기존 도금층의 두께는 약 $25 \mathrm{um} 45 \mathrm{um}$ 으로 분포하고 있으며[2324], 예열통전 이후 도금층의 두께는 약 $2.9 \mathrm{um} 4.8 \mathrm{um}$ 으

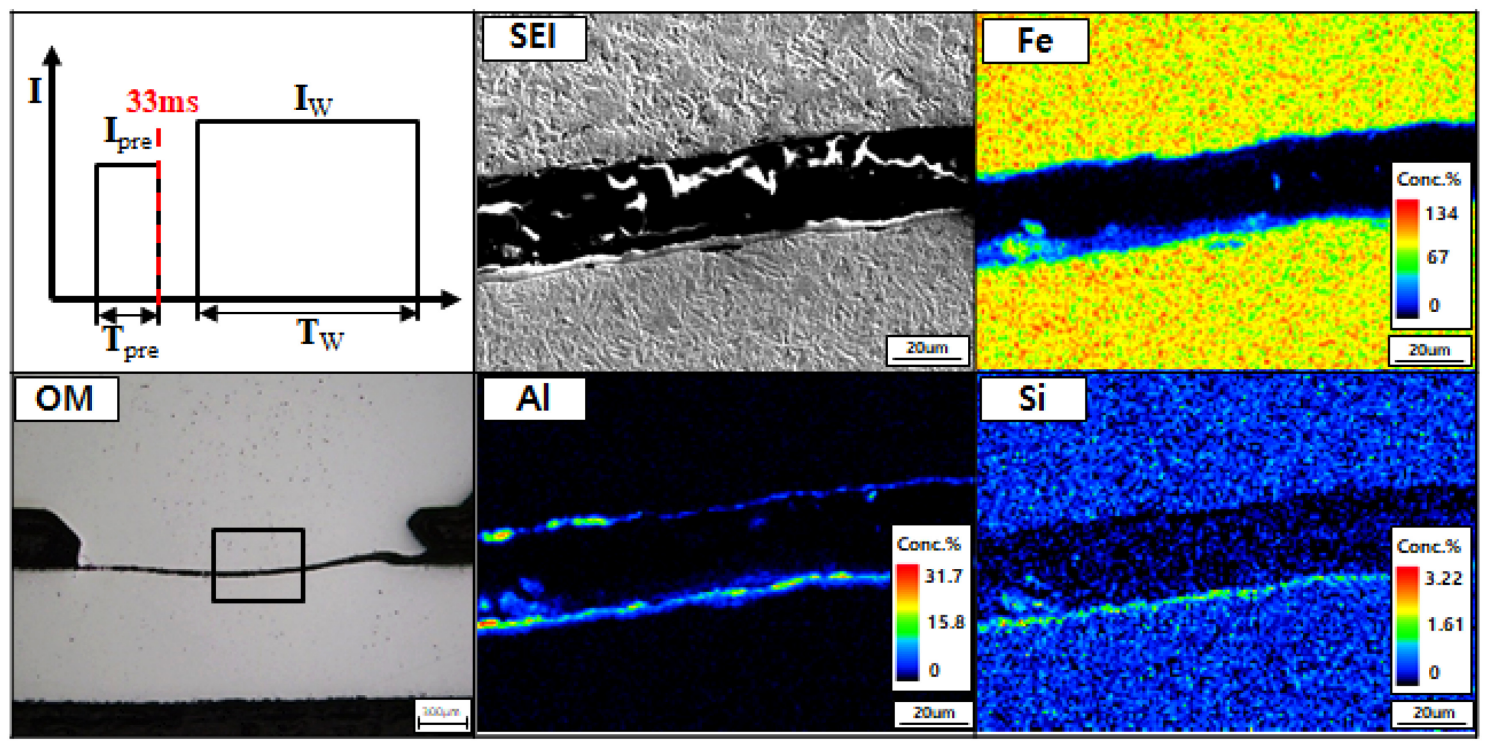

Fig. 11. EPMA mapping of the elemental distribution in the cross-section using preheat current. 


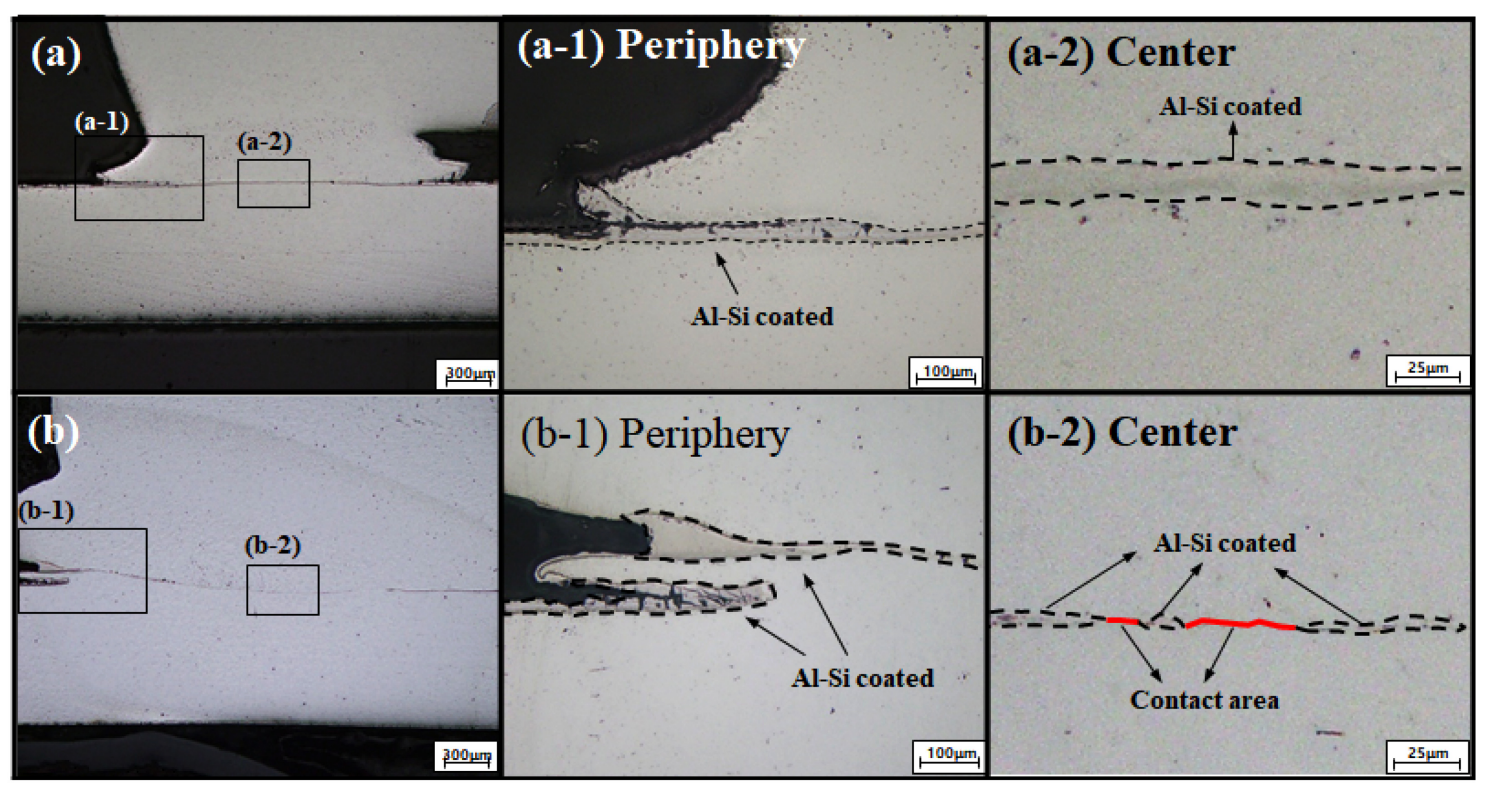

Fig. 12. Cross-section of interface during Tw $33 \mathrm{~ms}$ for various preheating conditions: (a) without preheating (b) with preheating.

로 약 10 배 가까이 감소한 것을 확인 할 수 있었다. 이는 예열 통전에 의해 용융된 도금층이 용접부 외각으로 밀려 남에 따라 감소한 것으로 판단된다.

예열 통전 이후 용접 초기 용융부계면에서 $\mathrm{Al}-\mathrm{Si}$ 도금층 의 거동을 분석하고자 그림 12 와 같이 실체화 현미경을 이용해 용접시간 $33 \mathrm{~ms}$ 일 때의 용접부 단면을 관찰하였 다. 그림 12 의 (a), (b)는 용접부 단면이고 (a-1), (b-1)는 용접부 외각, (a-2), (b-2)는 용접부 중심을 확대하여 관찰 한 결과이다. 조건 $\mathrm{W} / \mathrm{O} \mathrm{PHC}$ 의 경우 $\mathrm{Al}-\mathrm{Si}$ 도금층이 용 접부 외각과 중심부에 잔존하였으며, 이때 중심부에 남아 있는 $\mathrm{Al}-\mathrm{Si}$ 도금층의 두께는 약 10.35 22.77 um으로 관찰 되었다. 반면 $\mathrm{W} \mathrm{PHC}$ 조건의 경우 $\mathrm{Al}-\mathrm{Si}$ 도금층이 잔존 하지 않고 핫스탬핑강과 볼트돌기가 접촉된 부분과 용접부 외각쪽에서 관찰된 도금층의 두께는 최대 $4.14 \mathrm{um}$ 으로 관 찰되었으며 $\mathrm{Al}-\mathrm{Si}$ 도금층이 용융되어 용접부 외각에 축적 되어 응고된 것을 관찰하였다. 예열통전 유무에 따른 도금 층 두께의 차이는 $\mathrm{W} \mathrm{PHC}$ 조건의 경우 예열 통전에서 도금층을 제거하여 소량의 일부만 잔존된 상태에서 용접되 었으나 W/O PHC 용접 조건의 경우 용접부 돌기의 급격 한 붕괴가 발생하여 $\mathrm{Al}-\mathrm{Si}$ 도금층이 빠져나가지 못해 용접 부에 비교적 많은 양이 잔존된 것으로 판단된다.

저항 용접에 있어 동저항 그래프는 용접시간에 따른 저 항값의 변화를 통해 용접부의 용융거동에 대한 간접적인 예측신호이며 동저항 거동 분석을 통해 초기발열거동 및 용접 중 계면 최대온도, 전체 저항값을 비교함에 따라 용

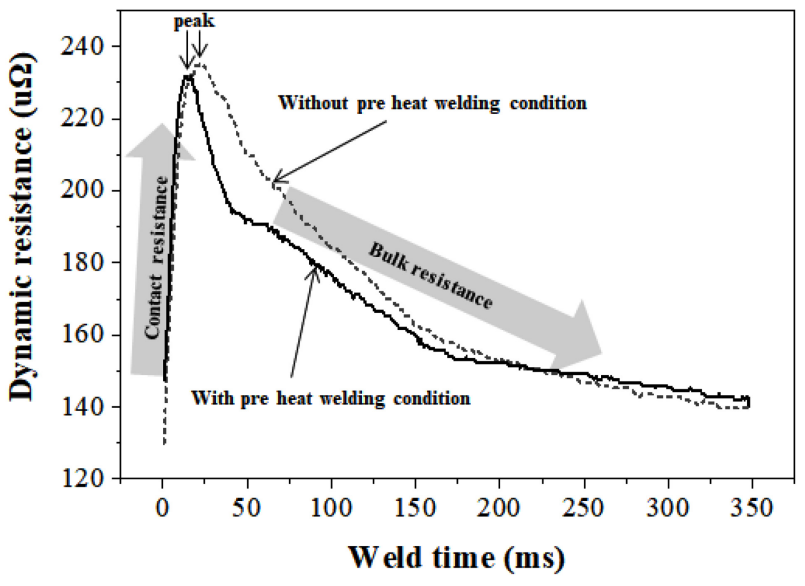

Fig. 13. Dynamic resistance curve with weld time for bolt projection welding at various preheating conditions (weld current $13 \mathrm{kA})$.

융거동 현상을 간접적으로 분석할 수 있다. 이에 예열 통 전 유무에 따른 용접현상을 간접적으로 분석하고자 예열통 전의 유무에 따른 용접조건 중 가장 높은 용착강도가 나타 난 $\mathrm{W} \mathrm{PHC}$ 조건 $13 \mathrm{kA}$ 일 때와 동일 조건인 $\mathrm{W} / \mathrm{O}$ $\mathrm{PHC}$ 조건의 용접조건 $13 \mathrm{kA}$ 일때의 동저항을 비교하여 그림 13에 나타내었다. 동일한 용접전류 $13 \mathrm{kA}$ 일때의 용접 조건이지만 $\mathrm{W} / \mathrm{O} \mathrm{PHC}$ 의 경우 중간날림이 발생하고 용착 강도가 확보되지 않은 조건이고, $\mathrm{W}$ PHC 조건의 경우 용 착강도가 확보된 안정적인 조건이다. 각 조건의 동저항 차 이는 Peak 동저항 이전 접촉 저항의 영향이 지배적인 구 


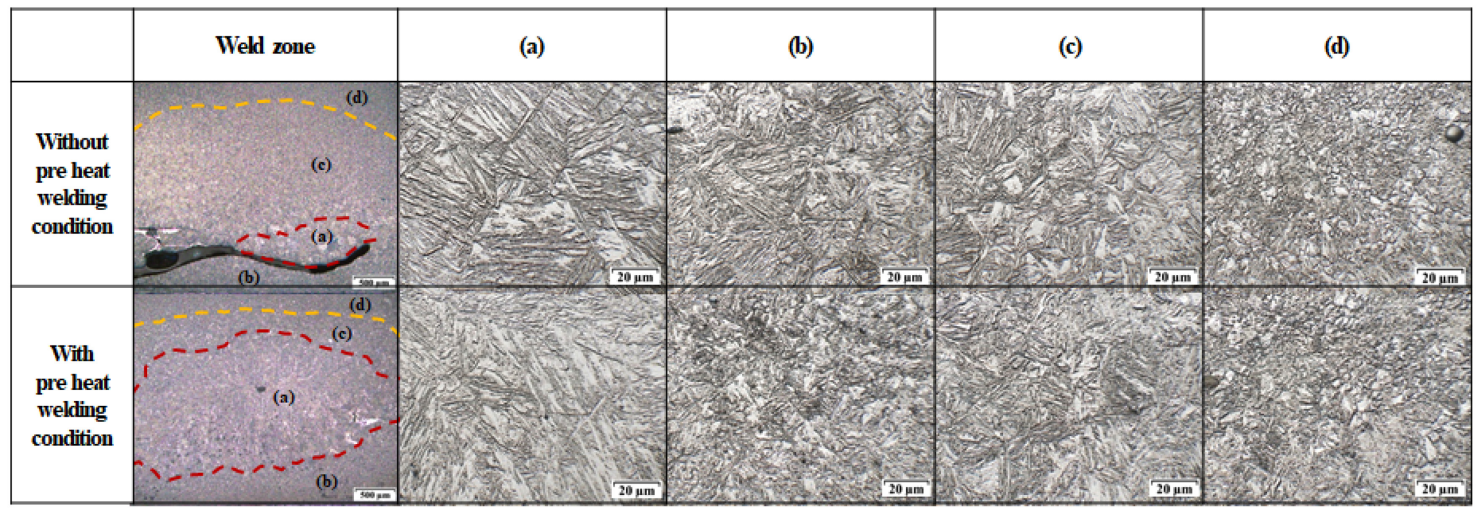

Fig. 14. Optical micrographs of the weld cross-section (a) Fusion zone, (b) Hot stamping boron steel heat affected zone, (c) Carbon steel bolt upper-critical heat affected zone, (d) Carbon steel bolt sub-critical heat affected zone.

간이 peak 동저항 까지 도달하는데 걸리는 시간은 $\mathrm{W} / \mathrm{O}$ PHC 조건이 약 $24 \mathrm{~ms}$ 로 W PHC 조건이 약 $16 \mathrm{~ms}$ 보다 늦게 도달하였으며 Peak 동저항 또한 더 높게 나타났다. 또한 계면의 접촉이 안정되고 용융부의 성장이 시작되는 Peak 동저항 이후 벌크 저항이 지배적인 구간에서는 약 $200 \mathrm{~ms}$ 이전까지 W/O PHC조건이 높게 나타났으며 $41 \mathrm{~ms}$ 일 때 최대 $23.8 \mathrm{u} \Omega$ 의 차이가 발생하였다 [25-27]. 이러한 동저항의 차이는 예열 통전에 의해 도금층이 외각 으로 밀려나고, 돌기가 일부 붕괴된 상태에서 용접전류가 인가되어 접촉저항의 영향이 지배적인 구간이 낮게 나타났 다 $[28,29]$. 저항은 입열 계산식 $\left(\mathrm{Q}=\mathrm{I}^{2} \mathrm{RT}\right)$ 에 따르면 발열 에 비례하기 때문에 동저항이 높은 것은 입열이 더 높다는 것을 의미하고 더 큰 용융부가 형성 될 수 있지만 예열 통전을 포함하지 않은 조건의 경우 좁은 접촉면적, 중심부 에 잔존된 $\mathrm{Al}-\mathrm{Si}$ 도금층에 의해 용접초기 용접부 계면에서 과도한 입열이 발생하여 중간날림으로 인한 기공이 형성되 었고 이에 통전되는 면적이 감소함으로써 벌크 저항의 영 향이 지배적인 구간에서 동저항이 높은 것으로 판단된다.

예열 통전은 $\mathrm{Al}-\mathrm{Si}$ 도금층을 외각으로 밀려나게 함과 동 시에 접촉면적을 충분히 확보하여 용접초기 급격한 저항발 열을 방지할 수 있으며 중간날림 등의 용접결함을 방지하 고 계면에 잔존하는 $\mathrm{Al}-\mathrm{Si}$ 도금층의 영향을 최소화함에 따 라 안정적인 용융부의 성장을 유도한다.

\section{5 용접부 미세조직 비교}

앞선 결과에서 용접부의 경도분포 및 용접부 형상 차이 의 원인을 분석하기 위해 용접조건 $13 \mathrm{kA}$ 일 때 용접 후 미세조직을 그림 14 와 같이 광학 현미경을 이용해 관찰하 였다. W/O PHC 용접조건 시편의 경우 용접부 중심아래 기공이 분포하고 있었으며 이는 중간날림에 의한 용융물의
배출에 기인해 발생한 것으로 판단된다. 반면 $\mathrm{W} \mathrm{PHC}$ 조 건의 경우 일반적인 저항용접부에서 관찰 할 수 있는 용접 부 조직이 관찰되었다. 일반적으로 저항 용접부의 미세조 직은 모재(Base Metal; $\mathrm{BM}$ ), 열영향부(Heat Affected Zone; HAZ), 용융부(Fusion Zone; FZ)로 분류된다. W/O $\mathrm{PHC}$ 조건의 용융부는 Ac3 온도 이상 상승되어 완전 오스 테나이트(Austenite) 상태로 마르텐사이트(Martensite) 조직 과 일부 베이나이트(Bainite)조직이 관찰되었다. W PHC 조건은 용융부는 일반적인 용접부 조직에서 관찰 할 수 있 는 Epitaxial 성장의 마르텐사이트가 응고조직 내에 분포하 였다 [30-33]. Al-Si 도금된 핫스탬핑강의 열영향부는 $\mathrm{AC} 3$ 온도 이상 가열되어 완전 오스테나이트 상태가 되었 다가 급냉 된 마르텐사이트 조직으로 관찰되었으며, $\mathrm{Al}-\mathrm{Si}$ 탄소강 볼트의 열영향부는 Ac3 온도 이상까지 상승한 Upper-critical 열영향부(UCHAZ)와 Ac1 이하의 온도까지 상승한 Sub-critical 열영향(SCHAZ)로 관찰되었다. 탄소강 볼트의 UCHAZ 에서는 마르텐사이트 조직과 일부 페라이 트 조직이 관찰되었고, $\mathrm{SCHAZ}$ 는 $\mathrm{AC} 1$ 온도 근처까지 상 승하여 상변태는 일어나지 않고 모재 대비 펄라이트와 페 라이트 조직이 미세화 되었다 [34-36].

결정립의 정확한 비교를 위해 대표적으로 용융부의 중심 을 $\mathrm{EBSD}$ 분석기법을 이용해 결정립의 크기를 측정하였다 (그림 15). 결정립의 크기는 $\mathrm{W} / \mathrm{O} \mathrm{PHC}$ 조건은 평균 약 $18.9 \pm 23.4 \mu \mathrm{m}, \mathrm{W}$ PHC 조건은 평균 약 $9.3 \pm 6.8 \mu \mathrm{m}$ 으 로 $\mathrm{W} / \mathrm{O} \mathrm{PHC}$ 조건의 Martensite Lath 크기가 더 큰 것 으로 관찰됐다. $\mathrm{W} / \mathrm{O} \mathrm{PHC}$ 시편의 경우 평균 결정립크기 를 초과하는 표준편차 값이 나타났는데, 이는 $66 \mu \mathrm{m}$ 크기 의 결정립이 측정영역에서 $13.7 \%$ 만큼의 면적을 차지함으 로써 나타난 결과이다. 이러한 용접부 미세조직의 차이는 $\mathrm{W} / \mathrm{O} \mathrm{PHC}$ 조건의 경우 용접 초기부터 발생한 중간날림으 


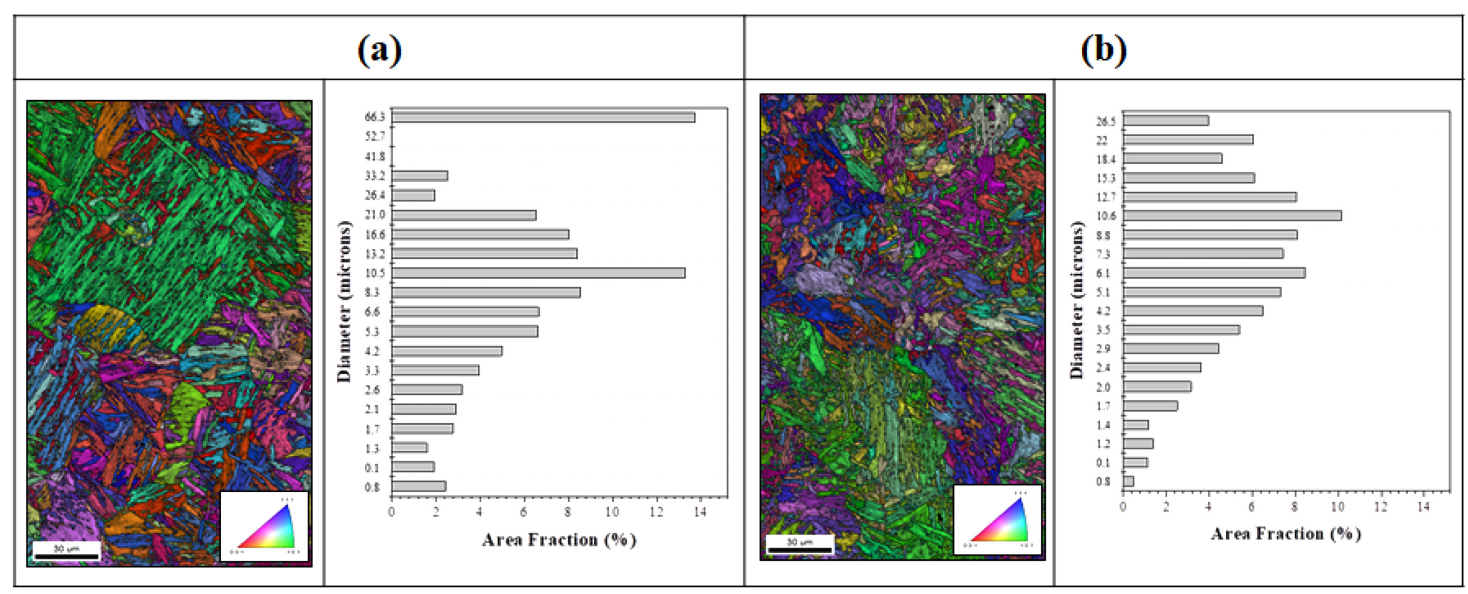

Fig. 15. EBSD maps of the weld cross-section at Fusion zone for various preheating conditions: (a) without preheating, (b) With preheating.

로 인해 용융물의 과도한 배출로 인해 용접부에 기공이 형 성되고 이후 고입열 및 기공에 의한 냉각속도가 저하되어 용접부의 결정립 크기가 증가되고 용융부에서의 Bainite 조 직이 생성 될 수 있는 분위기가 형성되어 나타난 차이로 판단된다. 과입열 및 냉각속도의 저하로 인해 열 영향을 가장 적게 받은 $\mathrm{SCHAZ}$ 를 제외한 나머지 부분에서 모두 $\mathrm{W} / \mathrm{O} \mathrm{PHC}$ 조건이 경도가 낮은 원인은, 용접부 계면에서 가까운 핫스탬핑강의 $\mathrm{HAZ}$ 부와 볼트 $\mathrm{UCHAZ}$ 는 용융부가 중간날림으로 인해 정상적으로 성장되지 못함에 따라 전극 과의 접촉이 불안정하여 냉각속도가 저하 되어 결정립이 비교적 조대화 됐기 때문이다 [37-40].

\section{4. 결 론}

본 연구에서는 예열통전 유무에 따른 용접부 단면 형상 과 미세조직 차이를 고찰하고, 예열통전의 $\mathrm{Al}-\mathrm{Si}$ 도금층 제 거 영향 최소화 효과를 분석하여 다음과 같은 결론을 도출 하였다.

- 예열통전 유무에 따른 용접성과 용융부 성장거동의 비교 결과 예열통전을 포함한 조건은 가용전류구간을 확보 되었으 며 용융부가 안정적으로 성장되는 것을 확인 할 수 있었다. 반면 예열 통전을 포함하지 않은 조건은 가용전류구간을 확 보하지 못하였으며 이는 용접초기부터 형성되는 기공에 의해 용착강도와 용접부 경도가 저하된 것으로 판단된다.

- 용접초기 시뮬레이션 결과 예열통전을 포함하지 않는 조건은 예열 통전을 포함한 조건에 비해 용접부 계면의 온 도상승 속도가 빨랐으며 이는 용접초기 접촉면적이 좁고 돌기의 빠른 붕괴속도로 인해 용접부 계면의 전류밀도가 높거나 불안정하였기 때문에 높은 저항발열이 발생한 것으
로 판단된다.

- 예열통전은 용접부 계면의 $\mathrm{Al}-\mathrm{Si}$ 도금층을 용접부 중 심에서 외각으로 밀어내 영향을 최소화 하고 용접초기 넓 은 접촉면적을 확보한 것으로 관찰됐으며 동저항 거동 분 석을 통한 실험적 검증 결과 접촉저항과 벌크저항의 영향 을 받는 동저항 구간이 낮게 관찰된 것을 봤을 때 용접부 의 급격한 저항 발열 발생을 방지하는 효과가 있는 것으로 판단된다.

- 용접부 미세조직 비교결과 예열통전을 포함한 용접조 건은 일반적인 용접부 조직이 관찰되었으나 예열통전을 포 함하지 않은 조건은 용접부 기공을 포함한 용접부 조직이 관찰되었으며 결정립의 평균크기 또한 비교적 더 크게 나 타났다. 이는 용접초기 높은 저항 발열에 의해 중간날림이 발생하여 기공이 형성되었고 과입열 및 냉각속도의 저하로 인해 용접부 미세조직이 조대화 되어 나타난 차이이다.

\section{ACKNOWLEDGEMENTS}

This study has been financially supported by the Ministry of Economy and Finance and conducted with the support of the Korea Institute of Industrial Technology as "Development of car body part utilizing Al-Si coated hot press forming steel project Ministry of Trade, Industry and Energy 20013403".

\section{REFERENCES}

1. K. Alexander, W. Daniel, and M. Marion, Phys. Procedia 56, 1410 (2014). 
2. H. Karbasian and A.E. Tekkaya, A review on hot stamping, J. Mater. Processing Technol. 210, 2013 (2010).

3. D. W. Fan and Bruno C. De Cooman, Steel res. Int. 83, 9999 (2012).

4. Z. X. Gui, Thermo-mechanical behavior of the Al-Si alloy coated hot stamping boron steel, Mater. Des. 60, 26 (2014).

5. D. W. Fan and Bruno C. De Cooman, Steel research int 83, 412 (2012).

6. C. W. Ji, Y. D. Kim, and Y. D. Park, Korean J. Met. Mater, 52, 931 (2014).

7. D. C. Saha, Sci. Technol. Weld. Join. 20, 708 (2015).

8. H. S. Choi, G. H. Park, W. S. Lim, and Kim. B. min. Journal of Mechanical Science and Technology, 25, 1543 (2011).

9. J. Luo, ISIJ, 59, 2, 305 (2019).

10. E.J. Chun, S.S. Lim, Y.T. Kim, K.S. Nam, Y.M. Kim, Y.W. Park, S.P. Murugan, and Y. Do Park, Met. Mater. Int. 25, 179 (2019).

11. S. S. Lim, Y.T. Kim, E.J. Chun, K.S. Nam, Y.W. Park, J.W Kim, and Y. Do Park, Korean J. Weld. Join, 34, 2, 1 (2016).

12. J.Y. Cheon, V. Vijayan, S. Murgun, Y. Do Park, J.H. Kim, J.Y. Yu, and C. Ji, J. Mech. Sci. Technol. 33, 1615 (2019).

13. R. Chen, M. Lou, Y. Li, B.E. Carlson, and J. Manuf. Process. 48, 31 (2019).

14. J. H. Kim, H. W. Jun, J. Y. Cheon, Y. D. Kim, and C. W. Ji, Korean J. Weld. Join, 38, 33 (2020).

15. M. Kimichi, Weld. J. 63, 58 (1984).

16. H. Zhang, Weld. J. 78, 373 (1999).

17. M. Pouranvari, A. Abedi, P. Marashi, and M. Goodarzi, Sci. Technol. Weld. Join. 3, 40 (1993)

18. Z. Han and J. E. Indacochea, J. Mater. Eng. Perform. 2, 438 (1993).

19. S. Ha, S.P. Murugan, K.P. Marimuthu, Y. Park, and H. Lee, J. Mater. Process. Technol. 263, 101 (2019).

20. M. A. Al-Jader, J. D. Cullen, N. Athi, A. Al-Shamma, J. Phys. Conf. Ser. 178, 012013 (2009).

21. Zhang and Wenqi. SORPAS-the professional software for simulation of resistance welding. DTU, Department of Manufacturing, Engineering and Management, (2002).
22. S.P. Murugan, K. Mahmud, C. Ji, I. Jo, and Y. Do Park, Weld. World. 63, 1613 (2019).

23. Z. xiang Gui, W. K. Liang, Y. Liu, and Y. S. Zhang, Mater. Des. 60, 26 (2014).

24. P. Hein, R. Kefferstein, and Y. Dahan, The International Conference "New Development in Sheet Metal Forming Technology", 163, Stuttgart, Germany (2006).

25. A.G. Livshits, Weld. J. 76, 383 (1997).

26. D.W. Dickinson, J.E. Franklin, and A. Stanya, Weld. J. 59 (1980).

27. B. Xing, Y. Xiao, Q.H. Qin, and H. Cui, Int. J. Adv. Manuf. Technol. 94, 327 (2018).

28. O.L.R. Ighodaro, E. Biro, and Y.N. Zhou, Metall. Mater. Trans. A Phys. Metall. Mater. Sci. 48, 745 (2017).

29. O. Ighodaro, Effects of Metallic Coatings on Resistance Spot Weldability of Hot Stamping Steel. MS thesis. University of Waterloo, (2017).

30. M.I. Khan, M.L. Kuntz, E. Biro, and Y. Zhou, Mater. Trans. 49, 1629 (2008).

31. Y.S. Jong, Y.K. Lee, D.C. Kim, M.J. Kang, I.S. Hwang, and W.B. Lee, Mater. Trans. 52, 1330 (2011).

32. B.H. Jung, J.P. Kong, and C.Y. Kang, J. Korean Inst. Met. Mater. 50, 224 (2012).

33. J. P. Gong, Korean J. Weld. Join, 29. 5, 99 (2011).

34. J. Jeong, S.-C. Park, G.-Y. Shin, C. W. Lee, T.-Y. Kim, and M. S. Choi, Korean J. Met. Mater. 56, 787 (2018).

35. S.G. Son, Y. Hwang, C.W. Lee, J.H. Yoo, and M. Choi, J. Korean Inst. Met. Mater. 57, 778 (2019).

36. M. H. OH, Korean J. Weld. Join, 31. 6, 96 (2013).

37. M. Pouranvari, S.P.H. Marashi, and D.S. Safanama, Mater. Sci. Eng. A. 528, 8344 (2011).

38. V. H. Baltazar Hernandez, S.K. Panda, M.L. Kuntz, and Y. Zhou, Mater. Lett. 64, 207 (2010).

39. Y. Hang, C. W. Lee, G.-Y. Shin, J. H. Yoo, and M. Choi, Korean J. Met. Mater. 57, 193 (2019).

40. J.-W. Kim, S. P. Murugan, N. H. Kang, and Y.-D. Park, Korean J. Met. Mater. 57, 715 (2019). 